\title{
Studies on formulation of RTS beverage from the blend of pomegranate, giloy and wheatgrass juice
}

\author{
- Syed Faisal Kamraan* and Dorcus Masih
}

Department of Food Process Engineering, Vaugh Institute of Agricultural Engineering and Technology (SHUATS), Naini, Prayagraj (U.P.) India

$*_{\text {Author for Correspondence }}$

Research chronicle : Received : 14.04.2019; Revised : 11.05.2019; Accepted : 21.05.2019

\begin{abstract}
SUMMARY:
Efforts have been made to prepare RTS beverage from the blend of pomegranate, giloy and wheatgrass juice and its physico-chemical properties and the mineral content were evaluated.The concentration of pomegrante juice was kept constant (10\%) and the addition of different levels of giloy and wheatgrass juice were done and based on the sensory evaluation from the semi trained panelists the final concentration of 5 per cent wheatgrass juice and 5 per cent of giloy juice were finalized. The prepared RTS beverage was analysed for moisture content, ash content, $\mathrm{pH}$, acidity, carbohydrate, potein, fat content, TSS, mineral content. Microbial analysis like total plate count, yeast and mold and total coliform count were also done along with storage studies which were carried out for 60 days at refrigerated and ambient temperature.
\end{abstract}

KEY WORDS : RTS beverage, Physio-chemical properties, Microbial analysis, Storage studies

How to cite this paper : Kamraan, Syed Faisal and Masih, Dorcus (2019). Studies on formulation of RTS beverage from the blend of pomegranate, giloy and wheat grass juice. Internat. J. Proc. \& Post Harvest Technol., 10(1) : 9-15. DOI: 10. 15740/HAS/IJPPHT/10.1/9-15. Copyright@ 2019: Hind Agri-Horticultural Society. 